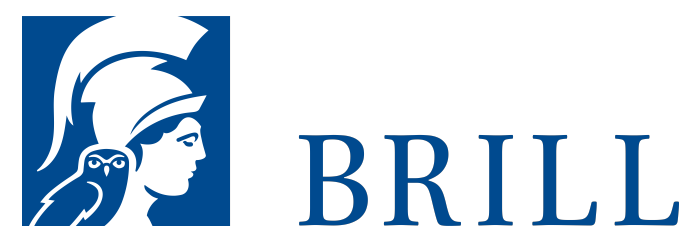

\title{
Narrative Structure and Discourse Constellations
}

An Analysis of Clause Function in Biblical Hebrew Prose

Author: Roy L. Heller

\section{Language:}

English

Subjects:

Linguistics,

Ancient Near

East and Egypt

Publisher: Brill

Series:

Harvard Semitic

Studies, Volume:

55

E-Book (PDF)

Released online:

25 Feb 2020

ISBN: 978-90-

04-38467-5

List price

USD $\$ 73.00$

Paperback

Publication date:

o1 Jan 2004

ISBN: 978-1-

57506-918-о

List price

USD $\$ 73.00$ 
For more information see brill.com

Order information: Order online at brill.com +44330 333 0049 | customerservices@brill.com Submission information: brill.com/authors

Titles published by Brill | Fink, Brill | mentis or Brill | Schöningh: +49(o)715413279216| brill@brocom.de 